\title{
SOLAR DRYER PERFORMANCE STUDY OF SOME CROPS (MINT, OKRA AND GRAPES) I - ASSESSING THE DRYING RATES
}

\author{
Mona M. A. Hassan*
}

ABSTRACT

Three crops were subjected to drying in the passive crop dryer. Crop samples were also open-sun dried as control treatment and the weight losses and temperature were taken. Mint leaves, okra and grapes were dried in the dryer and the same masses of samples were dried in the open-sun (control). The maximum stagnation temperature attained in the dryer is $66{ }^{\circ} \mathrm{c}$ and the corresponding values of solar radiation and ambient temperature were $832 \mathrm{~W} / \mathrm{m}^{2}$ and $36^{\circ} \mathrm{c}$, respectively. The overall heat loss coefficient of the dryer varied between 28.34 and $21.56 \mathrm{~W} / \mathrm{m}^{2}$ ${ }^{o} c$. All the drying process occurred in the falling rate period, starting from the initial moisture contents which are (83 wb or $488 \mathrm{db} \%$ for mint), (88.5 wb or $770 \mathrm{db} \%$ for okra) and (78 wb or $354 \mathrm{db}$ for\% grapes) to the final moisture content after drying were (1.18 and $19 \mathrm{db} \%$ for mint), (43 and $108 \mathrm{db} \%$ for okra) and (3.8 and $65.8 \mathrm{db} \%$ for grapes), for (solar dryer and natural drying) respectively. The assessment of the drying rate of the crops in the solar dryer and in opensun gives an average of $7.68 \mathrm{~g} / \mathrm{h}$ and $7.40 \mathrm{~g} / \mathrm{h}$ for mint leaves, $7.08 \mathrm{~g} / \mathrm{h}$ and $5.91 \mathrm{~g} / \mathrm{h}$ for okra and $7.17 \mathrm{~g} / \mathrm{h}$ and $5.92 \mathrm{~g} / \mathrm{h}$ for grapes respectively. For mint, drying efficiencies during different days of drying for the dryer and natural drying were (60.92, 7.11 and 2.84\%) and (55.51, 9.82 and $2.98 \%)$ on (first, second and third drying days), respectively and the averages were 23.62 and $22.77 \%$. For okra drying efficiencies during different days of drying for the dryer and natural drying were (42.93, 17.01 and 2.62\%) and (37.09, 15.36 and 4.49\%)on (first, second and third drying days), respectively and the averages were 20.85 and 18.98\%.For grapes, drying efficiencies during different days of drying for the dryer and natural drying were (34.27, 20.32 and 11.65\%) and (40.31, 8.88 and 5.46\%) on (first, second and third drying days), respectively and the average values were 22.05 and $18.21 \%$.

Keywords: crop dryer, weight losses, dryer efficiency, moisture content.

"Associate Prof. of Agric. Eng., Fac. of Agric., Zagazig Univ., Egypt. 


\section{INTRODUCTION}

rop drying in solar dryer reduces contamination of the crop by dirt, fungi, insects and animals. The study of the drying process has shown that it may be characterized in two stages in which the rate of drying varies differently. In the first stage, starting with a short heating up period, the drying rate is constant and maximum. The moisture content exceeds the maximum hygroscopic moisture content everywhere in the material. There is movement of moisture under the effect of capillary and osmotic force from the inside to the surface of the material and saturated vapour prevails over the surface. The second stage begins when the materials moisture content is everywhere less than maximum hygroscopic content. Drying rate decrease further in this case and tends asymptotically to zero. However, more significant controlling mechanism in the falling rate period is those of diffusion and capillary. Solar energy in recent times has been given more attention as an alternative to fossil fuel for drying and sometimes heating process as a result of alarming increase in the cost of fossil fuel energy. Drying crops by solar energy is of great economic importance allover the world. Most of the crops and grain harvest are lost to fungal and microbial attacks. These wastages could be easily prevented by proper drying which enhances storage of crops over a long period of time (Ezekoyi and Enebe, 2006). Some crops can be preserved and stored so that they can be of economic importance both to the farmer and the entire populace. Rural farmers do this by open air drying. Since this crops are easily contaminated by animal droppings and consequent infestation by fungal and bacteria. This method also prolongs drying and may result in the deterioration of the quality of the crops. Moreover, more labor is involved as the crops are watched to prevent attacks from birds and animals and crops are moved in and out during the day and night and from rain. A low temperature passive solar dryer has therefore been fabricated which will be appropriate for drying crops and grains at the low temperature and high relative humidity period of the year. This enables crops to be dried without cracking and hence minimizes the exposure of the crops to fungal and bacteria infestation and wastage and suitable for bulk drying (Butter and Goodrum, 1998). Pangavhane et al. 
(2002) developed a multipurpose natural convection solar dryer. They reported that "the drying airflow rate increased with increase in ambient temperature by the thermal buoyancy in the collector. In this study, grapes were dried and the qualitative analysis showed that the traditional drying of grape, shade drying and open sun drying required 15 and 7 days, respectively, while the natural convection solar dryer took only 4 days and produced better quality raisins. The drying time of the grapes is also reduced by $43 \%$ compared to the open sun drying. The developed natural convection solar dryer could produce the average temperature between 50 and $55^{\circ} \mathrm{c}$, which was optimum for dehydration of the grapes as well as for most of the fruits and vegetables". Gallali et al. (2000) reported that the mixed and indirect modes of drying were more effective than open sun, since the final moisture contents for grapes were about 13, 20 and 68\%, respectively. Akpinar (2010) reported that the enzymatic activity in plants inhibits and ceases at temperatures 50 to $60{ }^{\circ} \mathrm{c}$. For some active substances as volatile compounds, i.e., essential oils in herbs, the recommended temperature of drying should not exceed 35 to $45^{\circ} \mathrm{C}$. Al-Juamily et al. (2007) found that the best drying results for grapes are obtained at $65^{\circ} \mathrm{C}, 0.3 \mathrm{~m} / \mathrm{s}$ speed of air, and $30 \%$ relative humidity within the chamber. Radwan (2002) mentioned that, quality evaluated tests of the dried grape (raisins) showed that vitamin "C" content was the only chemical component significantly decreased during a sun drying method compared with solar drying method, dehydration ratio of solar dried raisin was higher than that of sun dried samples and sun dried raisin was lightly darker than solar dried samples. Abdel-Galil and El-Nakib (2008) reported that the essential oil content of fresh mint, direct solar dryer and indirect solar dryer were 2.98,1.76 and 1.64 respectively, while chlorophyll $(\mathrm{A}, \mathrm{B})$ contents of fresh mint, direct solar dryer and indirect solar dryer were $(6.77,4.20),(4.10,1.96)$ and $(3.54,1.82)$ respectively. Doymaz (2011) found that the time taken for drying of okra from the initial moisture contents of $88.7 \%$ (wb) to final moisture content of around $15 \pm 0.5 \%$ (wb) were $100 \mathrm{~h}$ in open sun drying. Mohamed et al. (2010) reported that using the indirect solar dryer for drying okra with air flow rate of $0.075 \mathrm{~m}^{3} / \mathrm{s}$ gave the best results. The objective of this work is 
PROCESS ENGINEERING

to evaluate the drying rate of three crops: mint leaves, okra and grapes inside a solar crop dryer comparing with the open-sun drying as control.

\section{MATERIALS AND METHODS}

\section{Description of the solar dryer:}

The solar dryer was designed and manufactured in El-Zagazig, Sharkia governorate (longitude $=35^{\circ} 30^{\circ}$ and latitude $=31^{\circ} 31^{\circ}$ ).

The main components of each drying system are:-

\section{1- Solar dryer}

The solar dryer $(100 \times 50 \times 40 \mathrm{~cm})$ is made of wood and single layered transparent glass which serves as a solar collector that brings about the transformation of solar radiation to heat energy needed for proper drying process inside the dryer. Cooler air goes into the dryer through the chimney $(20 \times 20 \times 20 \mathrm{~cm})$ and the heated air leaves the dryer by convection which would hasten the drying of the crops. Solar collector area is $0.5 \mathrm{~m}^{2}$. The drying chamber was equipped by one drying shelf which made of stainless steel screen mesh. The dryer is shown in figures (1 and 2).

\section{2 - Open Sun Draying}

Consists of tray which made of wooden frame $(95 \times 45 \mathrm{~cm})$ and stainless steel screen mesh in the bottom.

\section{Drying experiments}

All fresh crops (mint, okra and grape) used for the drying experiments were obtained

from local market. The samples were stored in closed plastic bag at $4^{\circ} \mathrm{c}$ refrigerator

before they were used in this study. Before the drying process, the samples were taken out of the refrigerator and leaves of the leafy vegetables were separated from stems. To determine the initial moisture content, three $10 \mathrm{~g}$ of samples were dried in an oven

at $105^{\circ} \mathrm{C}$ for $24 \mathrm{~h}$ and averages were reported. The samples were spread in a single layer on the shelf inside the dryer and the same mass spread in a single layer on a tray as the open sun. Moisture contents of samples were determined at each hour interval. When the samples weights at three consecutive times were constant, the drying process was cut and the 
moisture content at that time was considered as the equilibrium moisture content.

\section{Measurements}

Weight of samples was measured using electric balance (accuracy $0.01 \mathrm{~g}$ and maximum weight $3000 \mathrm{~g}$ ). Solar radiation and temperature of ambient air were measured by "Watchdog" weather station model 900 ET. The Weather station measures wind speed $(0-175 \mathrm{mph}) \pm 5 \%$, wind direction $\left(2^{\circ}\right.$ increments $) \pm 7^{\circ}$, temperature $\left(-30^{\circ}: 100^{\circ} \mathrm{c}\right)$, relative humidity $(20-100 \%) \pm 3 \%$, rainfall $(0.01-0.25 \mathrm{~cm}) \pm 2 \%$ and solar radiation $\left(1-1250 \mathrm{~W} / \mathrm{m}^{2}\right)$.Air temperature inside the dryer was recorded at different positions using thermometers with accuracy of 1 ${ }^{\circ} \mathrm{c}$ with maximum of $100^{\circ} \mathrm{c}$ and with calibrated thermocouples connected to a multi channel digital display with an accuracy of 0.05 ${ }^{\circ} \mathrm{c}$. Moisture content was measured using the electric oven. Humidity was measured using Klima Guard digital thermo-hygrometer, the range for relative humidity form (1 to $99 \%)$ with accuracy of $( \pm 3.5$ $\%)$. Air velocity was measured using the anemometer model, the range for air velocity form (0 to $45 \mathrm{~m} / \mathrm{s})$ with accuracy of $( \pm 0.3 \mathrm{~m} / \mathrm{s})$.

\section{Determination of dryer thermal efficiency:}

\section{Thermal performance of the solar collector:}

The thermal performance of the solar collector can be described in terms of several parameters which are usually employed to assess that performance. These parameters and their effect on thermal performance can be calculated according to Shewen et al. (1980) as follows:

\section{Solar energy available (Q): $Q=R A_{c}, W$}

Where $: R$ : Solar energy flux incident on the surface of solar collector, $\mathrm{W} / \mathrm{m}^{2}$ and $\mathrm{A}_{\mathrm{c}}$ : Surface area of the solar collector, $\mathrm{m}^{2}$.

2. Absorbed solar energy $\left(\mathbf{Q}_{\mathrm{a}}\right): Q_{a}=\tau R A_{c}, W$

Where: $\tau$ : Effective transmittance of solar collector cover system, decimal.

3. Absorption efficiency $\left(\boldsymbol{\eta}_{\mathrm{a}}\right): \eta_{a}=\left(Q_{a} / Q\right) \times 100, \%$

4. Useful heat gain to storage $\left(\mathbf{Q}_{\mathbf{c}}\right): Q_{c}=m c_{p}\left(T_{a o}-T_{a i}\right), W$

Where: m: Mass flow rate of air, $\mathrm{kg} / \mathrm{s}, \mathrm{c}_{\mathrm{p}}$ : Specific heat of air, $\mathrm{J} / \mathrm{kg} /{ }^{\circ} \mathrm{c}$, $\mathrm{T}_{\mathrm{ao}}$ : Outlet temperature of air, ${ }^{\circ} \mathrm{C}$ and $\mathrm{T}_{\mathrm{ai}}$ : Inlet temperature of air, ${ }^{\circ} \mathrm{C}$.

5. Heat transfer efficiency $\left(\boldsymbol{\eta}_{\mathbf{h}}\right): \eta_{n}=\left(Q_{c} / Q_{a}\right) \times 100, \%$ 
6. Solar collector heat losses $\left(\mathbf{Q}_{\mathbf{L}}\right): Q_{L}=Q_{a}-Q_{c} \quad, W$

7. Overall thermal efficiency $\left(\boldsymbol{\eta}_{\mathrm{s}}\right): \eta_{s}=\left(Q_{c} / Q\right) \times 100, \%$

\section{Drying Efficiency:}

Amount of heat required to evaporate the moisture inside the product is called as drying efficiency. Total heat in case of solar dryer is the availability of solar radiation on collector surface of the dryer. This drying efficiency was calculated by equation, $\eta_{d}=W \times l / A_{c} \times I_{c} \times t, \%$ Where, $W=$ Moisture evaporated $(\mathrm{kg}), l=$ Latent heat of vaporization of water, $2320(\mathrm{~kJ} / \mathrm{kg}), I_{c}=$ Isolation upon collector, $\left(\mathrm{W} / \mathrm{m}^{2}\right), A_{c}=$ Area of collector $\left(\mathrm{m}^{2}\right)$ and $\mathrm{t}=$ Time of drying ( $\mathrm{s}$ ).

\section{The overall heat loss coefficient:}

The overall heat loss coefficient of the dryer based on aperture area was calculated from the experimental data as: $U=I \tau\left(T_{s}-T_{a}\right), W / m^{2^{o}} c$ Where: I: solar radiation incident on aperture $\left(\mathrm{W} / \mathrm{m}^{2}\right)$; Ts: stagnation temperature $\left({ }^{\circ} \mathrm{c}\right)$; Ta: ambient temperature $\left({ }^{\circ} \mathrm{c}\right)$ and $\tau$ : transmissivity of glass cover (0.85).

Moisture content (MC): $M C=\left(M_{i}-M_{f}\right) / M_{i}, \%$

Where $\mathrm{M}_{\mathrm{i}}$ : Mass of sample before drying $(\mathrm{g})$ and $\mathrm{M}_{\mathrm{f}}$ : Mass of sample after drying (g).

Moisture Loss (ML): The moisture loss (g) is given as: $M L=M_{i}-M_{f}, g$

Average drying rate $\left(\mathbf{R}_{\mathbf{d}}\right): R_{d}=\frac{M_{t-d t}-M_{t}}{d t} \mathrm{~g} / \mathrm{h}$

Where $: \mathrm{M}_{\mathrm{t}-\mathrm{dt}}$ and $\mathrm{M}_{\mathrm{t}}$ are the moisture contents at $\mathrm{t}-\mathrm{dt}$ and $\mathrm{t}$, respectively(db\%), and $\mathrm{dt}$ is the drying time period(h).

\section{RESULTS AND DISCUSSION}

\section{Test at no load}

The experiments at no load were conducted during the month of September 2013. All openings of air outlet were closed to determine stagnation temperature of the dryer with zero useful heat gain. The dryer was placed in the south facing the sun from 10:00 a.m. and the experiment was continued up to 4:00 p.m. Solar irradiation on the aperture of the dryer, ambient temperature and air temperature in the dryer was recorded every an hour. Figure (3) shows the variation of 
temperature in the dryer, ambient temperature and solar radiation intensity during the day. The maximum stagnation temperature attained in the dryer is $66^{\circ} \mathrm{c}$ and the corresponding values of solar radiation and ambient temperature were $832 \mathrm{~W} / \mathrm{m}^{2}$ and $36{ }^{\circ} \mathrm{c}$, respectively. The overall heat loss coefficient of the dryer based on aperture area was calculated from the experimental data given in figure (3). The values varied between 28.34 and $21.56 \mathrm{~W} / \mathrm{m}^{2 \mathrm{o}} \mathrm{c}$. Then, the arithmetic average of these values was taken as the average overall heat loss coefficient of the dryer and it was found to be $24.95 \mathrm{~W} / \mathrm{m}^{20} \mathrm{c}$.
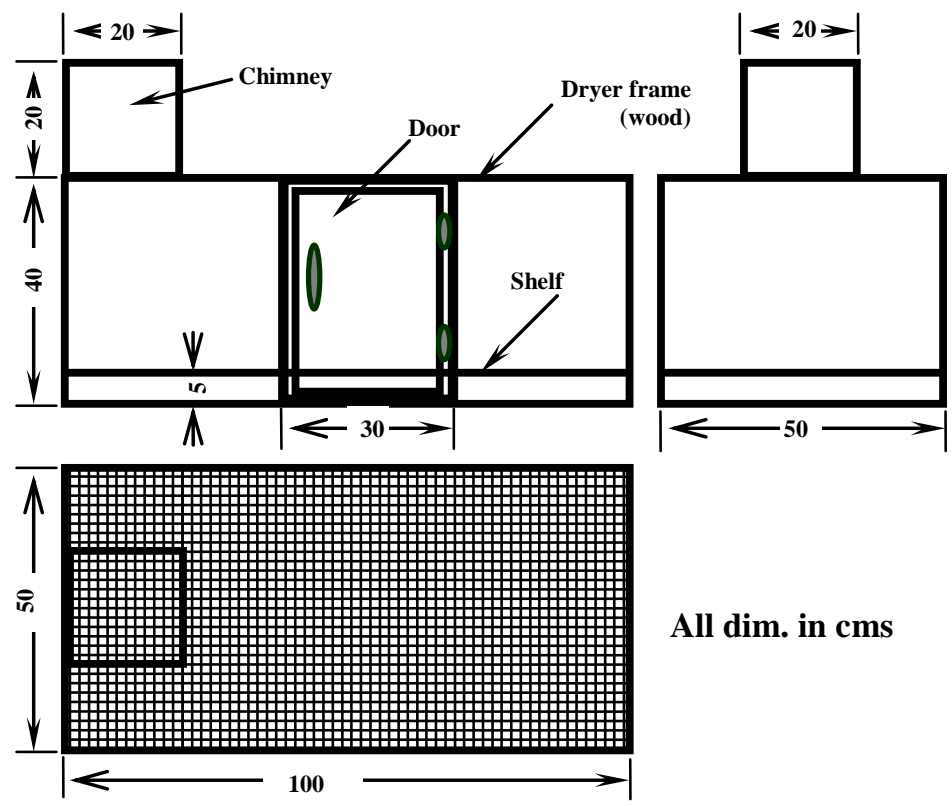

All dim. in cms

Figure (1): Schematic diagram of the solar dryer.

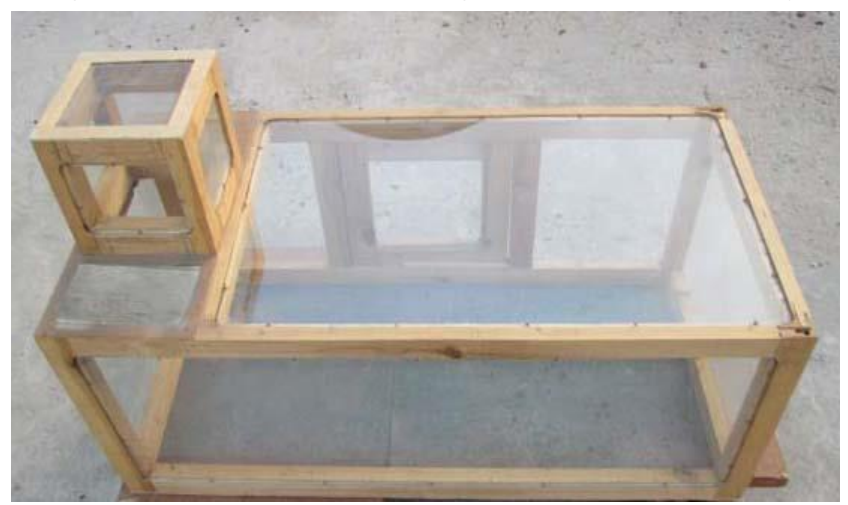

Figure (2): The solar dryer. 


\section{Test with load}

Mint leaves, okra and grapes were dried in the dryer and same samples in the open- air (control). At the end of the first day, on visual observation, very large void spaces could be seen from the products in the dryer. This was due to shrinkage of products during drying. The results for mint leaves, okra and grapes respectively of the tests are recorded in Tables 1 to 6. It is apparent that moisture content decreases continuously with drying time. As indicated in these curves figure (4, 5 and 6), there was no constant rate period in drying of mint, okra and grapes. All the drying processes occurred in the falling rate period, starting from the initial moisture content ( $83 \mathrm{wb}$ or $488 \mathrm{db} \%$ for mint), (88.5 wb or $770 \mathrm{db} \%$ for okra) and (78 wb or $354 \mathrm{db}$ for\% grapes) to the final moisture content after drying were (1.18 and $19 \mathrm{db} \%$ for mint), (43 and $108 \mathrm{db} \%$ for okra) and (3.8 and $65.8 \mathrm{db} \%$ for grapes), for (solar dryer and natural drying) respectively. These results are in agreement with the observations of earlier researchers (Lahsasni et al. 2004; Togrul and Pehlivan, 2004).

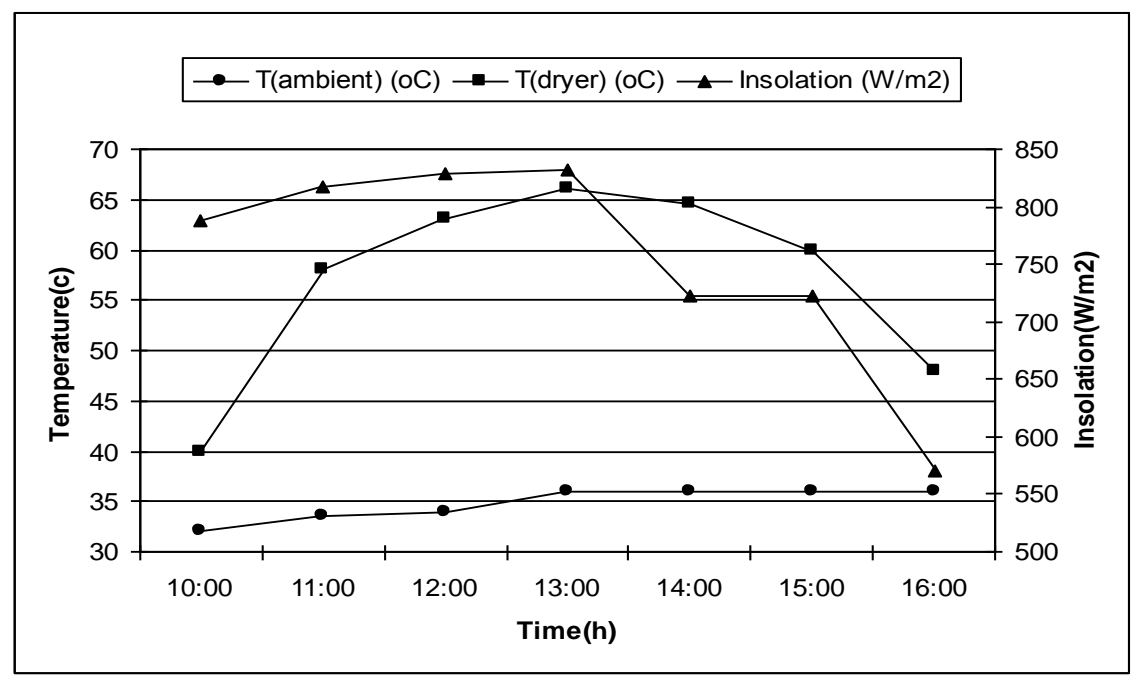

Figure (3) The variation of temperature in the dryer, ambient temperature and solar radiation intensity during (15/9/2013) 
Table 1: Mint leaves sample inside the solar dryer.

\begin{tabular}{|c|c|c|c|c|c|c|}
\hline Day & $\begin{array}{c}\text { Initial } \\
\text { mass }\left(\mathrm{M}_{\mathrm{i}}\right) \\
, \mathrm{g}\end{array}$ & $\begin{array}{c}\text { Final } \\
\text { mass } \\
\left(\mathrm{M}_{\mathrm{i}}\right), \mathrm{g}\end{array}$ & $\begin{array}{c}\text { Mass } \\
\text { diff. } \\
\left(\mathrm{M}_{\mathrm{i}}-\right. \\
\left.\mathrm{M}_{\mathrm{g}}\right), \mathrm{g}\end{array}$ & $\begin{array}{c}\text { Moisture } \\
\text { content } \\
(\text { w.b. }) \\
\%\end{array}$ & $\begin{array}{c}\text { Ambient } \\
\text { temp. } \\
{ }_{\mathrm{c}}\end{array}$ & $\begin{array}{c}\text { Dryer } \\
\text { temp., } \\
{ }_{\mathrm{c}}\end{array}$ \\
\hline 1 & 3000 & 860 & 2140 & 41.39 & 37 & 56 \\
\hline 2 & 860 & 610 & 250 & 17.37 & 37 & 55 \\
\hline 3 & 610 & 510 & 100 & 1.17 & 36.5 & 55 \\
\hline
\end{tabular}

Table 2: Mint leaves sample in open sun (control test).

\begin{tabular}{|c|c|c|c|c|c|}
\hline Day & $\begin{array}{c}\text { Initial } \\
\text { mass }\left(\mathrm{M}_{\mathrm{i}}\right), \\
\mathrm{g}\end{array}$ & $\begin{array}{c}\text { Final mass } \\
\left(\mathrm{M}_{\mathrm{i}}\right), \mathrm{g}\end{array}$ & $\begin{array}{c}\text { Mass diff. } \\
\left(\mathrm{M}_{\mathrm{i}}-\mathrm{M}_{\mathrm{g}}\right), \\
\mathrm{g}\end{array}$ & $\begin{array}{c}\text { Moisture } \\
\text { content(w.b. }) \\
, \%\end{array}$ & $\begin{array}{c}\text { Ambient } \\
\text { temp. } \\
{ }_{\mathrm{c}} \mathrm{c}\end{array}$ \\
\hline 1 & 3000 & 1050 & 1950 & 52 & 37 \\
\hline 2 & 1050 & 705 & 345 & 28.50 & 37 \\
\hline 3 & 705 & 600 & 105 & 16 & 36.5 \\
\hline
\end{tabular}

Table 3: Grapes sample inside the solar dryer.

\begin{tabular}{|c|c|c|c|c|c|c|}
\hline Day & $\begin{array}{c}\text { Initial } \\
\text { mass } \\
\left(\mathrm{M}_{\mathrm{i}}\right), \mathrm{g}\end{array}$ & $\begin{array}{c}\text { Final } \\
\text { mass } \\
\left(\mathrm{M}_{\mathrm{i}}\right), \mathrm{g}\end{array}$ & $\begin{array}{c}\text { Mass } \\
\text { diff. } \\
\left(\mathrm{M}_{\mathrm{i}}-\right. \\
\left.\mathrm{M}_{\mathrm{g}}\right), \mathrm{g}\end{array}$ & $\begin{array}{c}\text { Moisture } \\
\text { content(w.b. }) \\
, \%\end{array}$ & $\begin{array}{c}\text { Ambient } \\
\text { temp., } \\
{ }_{\mathrm{c}}\end{array}$ & $\begin{array}{c}\text { Dryer } \\
\text { temp., } \\
{ }_{\mathrm{c}}\end{array}$ \\
\hline 1 & 3000 & 1796 & 1204 & 63.75 & 35 & 57.5 \\
\hline 2 & 1796 & 1082 & 714 & 49.23 & 32.5 & 52 \\
\hline 3 & 1082 & 675.80 & 406.2 & 3.67 & 32 & 54 \\
\hline
\end{tabular}

Table 4: Grapes sample in Open sun (control test).

\begin{tabular}{|c|c|c|c|c|c|}
\hline Day & $\begin{array}{c}\text { Initial mass } \\
\left(\mathrm{M}_{\mathrm{i}}\right), \mathrm{g}\end{array}$ & $\begin{array}{c}\text { Final mass } \\
\left(\mathrm{M}_{\mathrm{i}}\right), \mathrm{g}\end{array}$ & $\begin{array}{c}\text { Mass diff. } \\
\left(\mathrm{M}_{\mathrm{i}}-\mathrm{M}_{\mathrm{g}}\right), \mathrm{g}\end{array}$ & $\begin{array}{c}\text { Moisture } \\
\text { content(w.b. }) \\
, \%\end{array}$ & $\begin{array}{c}\text { Ambient } \\
\text { temp., } \\
{ }_{\mathrm{c}}\end{array}$ \\
\hline 1 & 3000 & 1584 & 1416 & 58.90 & 35 \\
\hline 2 & 1584 & 1272 & 312 & 48.82 & 32.5 \\
\hline 3 & 1272 & 1080 & 192 & 39.72 & 32 \\
\hline
\end{tabular}


Table 5: Okra sample inside the solar dryer.

\begin{tabular}{|c|c|c|c|c|c|c|}
\hline Day & $\begin{array}{c}\text { Initial } \\
\text { mass } \\
\left(\mathrm{M}_{\mathrm{i}}\right), \mathrm{g}\end{array}$ & $\begin{array}{c}\text { Final } \\
\text { mass } \\
\left(\mathrm{M}_{\mathrm{i}}\right), \mathrm{g}\end{array}$ & $\begin{array}{c}\text { Mass } \\
\text { diff. } \\
\left(\mathrm{M}_{\mathrm{i}}-\right. \\
\left.\mathrm{M}_{\mathrm{g}}\right), \mathrm{g}\end{array}$ & $\begin{array}{c}\text { Moisture } \\
\text { content(w.b. }) \\
\%\end{array}$ & $\begin{array}{c}\text { Ambient } \\
\text { temp., } \\
{ }_{\mathrm{c}}\end{array}$ & $\begin{array}{c}\text { Dryer } \\
\text { temp., } \\
{ }_{\mathrm{c}}\end{array}$ \\
\hline 1 & 3000 & 1281 & 1719 & 73.07 & 33.5 & 48.5 \\
\hline 2 & 1281 & 600 & 681 & 42.50 & 34.5 & 58 \\
\hline 3 & 600 & 495 & 105 & 30.30 & 34.5 & 59.5 \\
\hline
\end{tabular}

Table 6: Okra sample in Open sun (control test).

\begin{tabular}{|c|c|c|c|c|c|c|}
\hline Day & $\begin{array}{c}\text { Initial } \\
\text { mass } \\
\left(\mathrm{M}_{\mathrm{i}}\right), \mathrm{g}\end{array}$ & $\begin{array}{c}\text { Final } \\
\text { mass } \\
\left(\mathrm{M}_{\mathrm{i}}\right), \mathrm{g}\end{array}$ & $\begin{array}{c}\text { Mass } \\
\text { diff. } \\
\left(\mathrm{M}_{\mathrm{i}}-\right. \\
\left.\mathrm{M}_{\mathrm{g}}\right), \mathrm{g}\end{array}$ & $\begin{array}{c}\text { Moisture } \\
\text { content(w.b. }) \\
\%\end{array}$ & $\begin{array}{c}\text { Ambient } \\
\text { temp., } \\
{ }_{\mathrm{c}} \mathrm{c}\end{array}$ & $\begin{array}{c}\text { Dryer } \\
\text { temp., } \\
{ }_{\mathrm{c}} \mathrm{c}\end{array}$ \\
\hline 1 & 3000 & 1515 & 1485 & 77.22 & 33.5 & 33.5 \\
\hline 2 & 1515 & 900 & 615 & 61.66 & 34.5 & 34.5 \\
\hline 3 & 900 & 720 & 180 & 52.08 & 34.5 & 34.5 \\
\hline
\end{tabular}

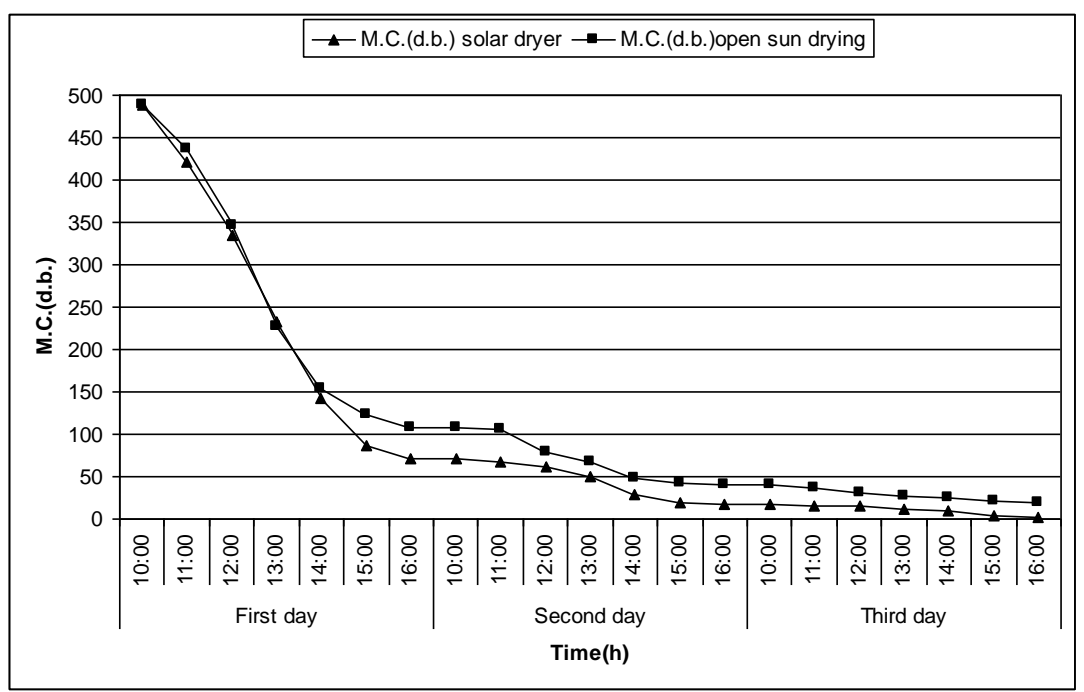

Figure (4) Variation of moisture content with drying time of mint in solar dryer and open sun. 


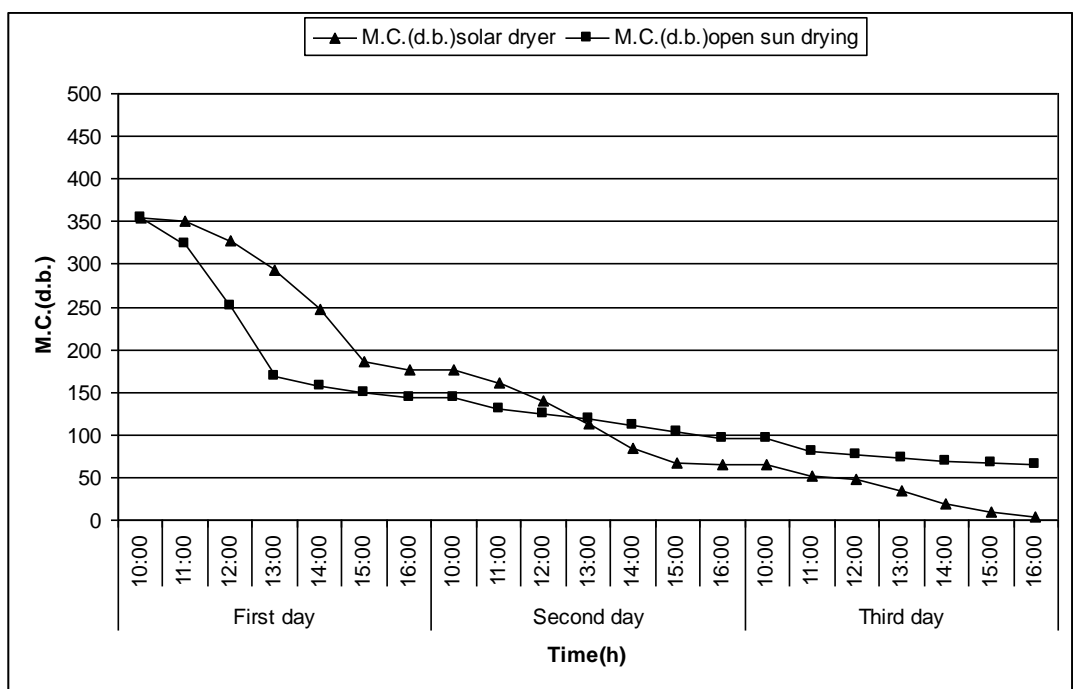

Figure (5) Variation of moisture content with drying time of grapes in solar dryer and open sun.

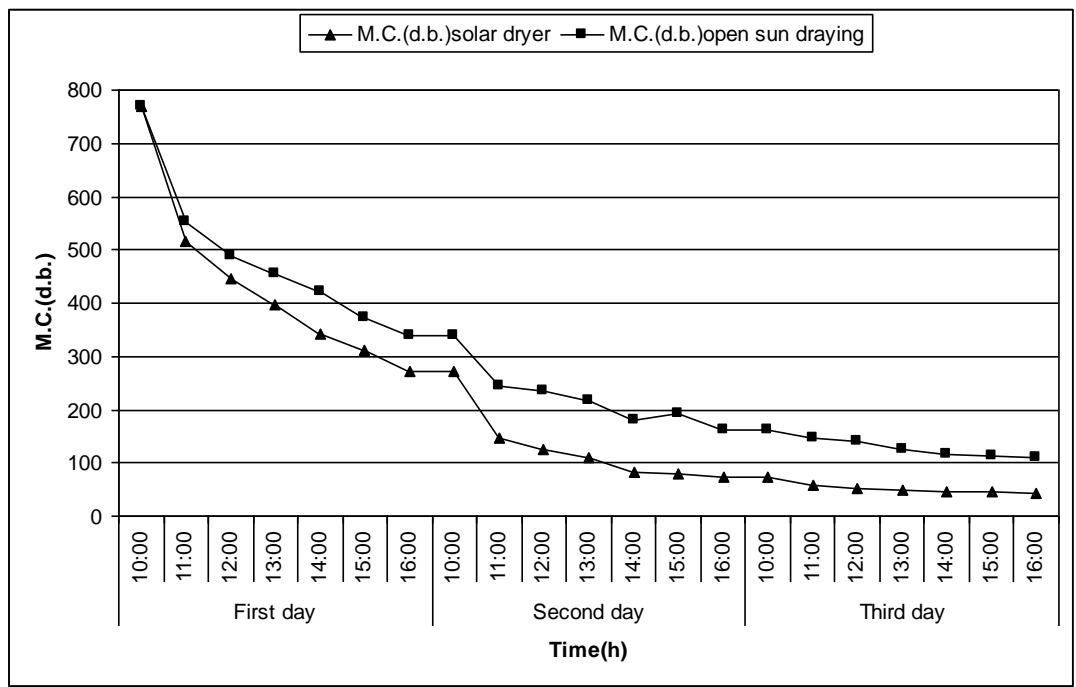

Figure (6) Variation of moisture content with drying time of okra in solar dryer and open sun.

Figures (7, 8 and 9) showed the rate of drying of crop samples in the solar dryer and in the open sun. The assessment of the drying rate of the crops in the solar dryer and in open-sun gives an average of 7.68 and $7.40 \mathrm{~g} / \mathrm{h}$ for mint leaves, $7.17 \mathrm{~g} / \mathrm{h}$ and $5.92 \mathrm{~g} / \mathrm{h}$ for grapes and $7.08 \mathrm{~g} / \mathrm{h}$ and $5.91 \mathrm{~g} / \mathrm{h}$ for okra. Figure (7) showed that for mint leaves sample, 
drying progressed rapidly in the solar dryer and in open-sun on the first day of exposure while on the second day, the difference in the rate of drying is almost the same and this may be attributed to low sun intensity on that day.

In the third day of the experiment, it can be seen that the rate of drying was much higher for samples in the solar dryer than in the open-sun. This same trend is observed for the rate of drying of grapes and okra shown in Figures ( 8 and 9). The result of the analysis indicated that mint leaves has higher drying rates than grapes and okra.

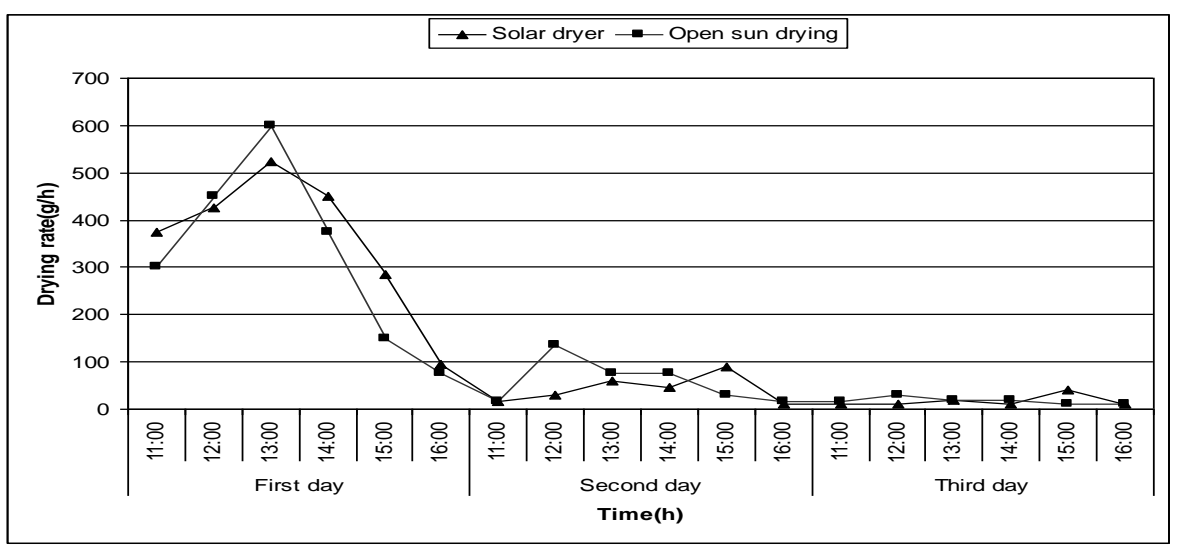

Figure( 7) Variation of drying rate with drying time of mint in solar dryer and open sun .

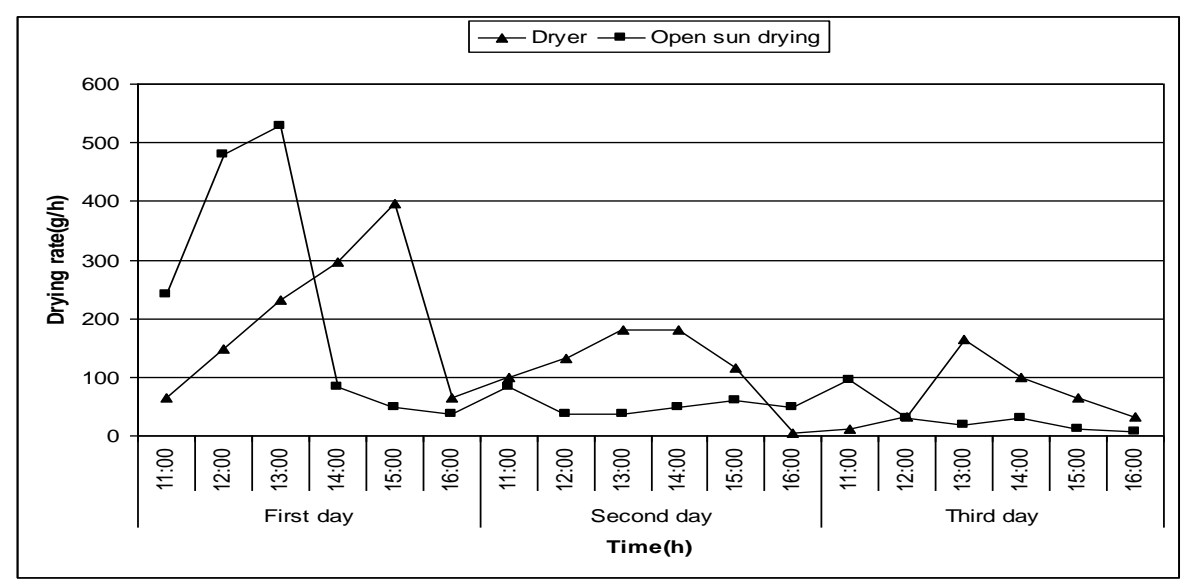

Figure(8) Variation of drying rate with drying time of grapes in solar dryer and open sun . 


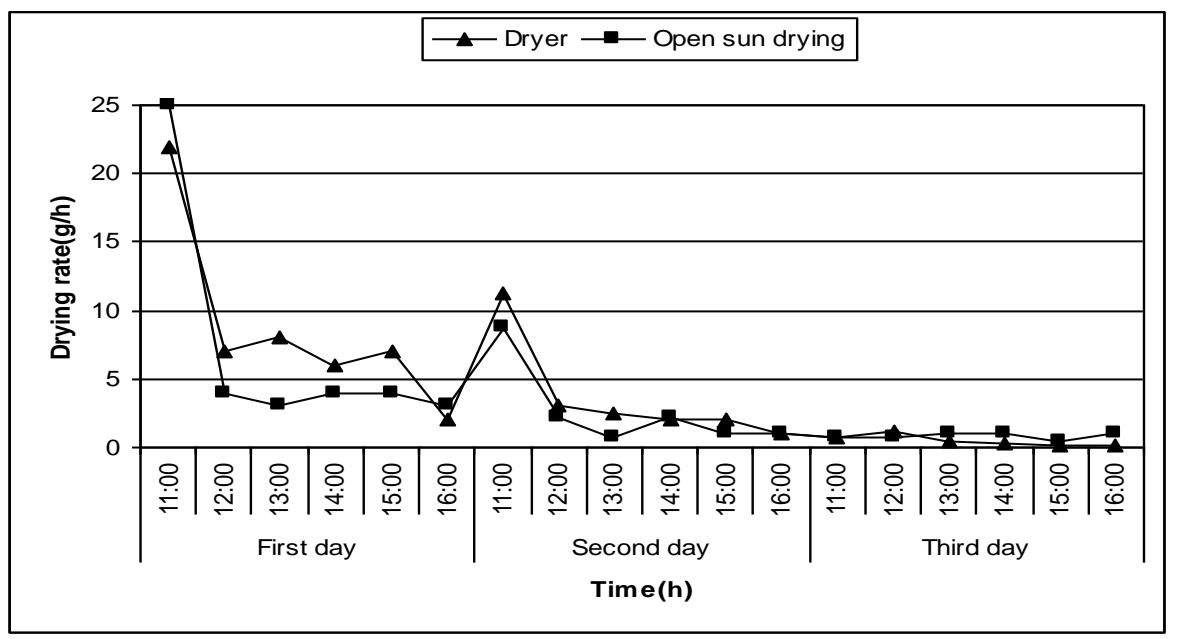

Figure (9) Variation of drying rate with drying time of okra in solar dryer and open sun.

\section{Drying efficiency:}

Drying efficiencies during different days of drying for the dryer and natural drying were (34.27, 20.32 and 11.65\%), (40.31, 8.88 and 5.46\%) on first, second and third drying days, for grapes respectively and the averages were 22.05 and $18.21 \%$, drying efficiencies during different days of drying for the dryer and natural drying were (60.92, 7.11 and $2.84 \%),(55.51,9.82$ and $2.98 \%$ ) on first, second and third drying days, for mint respectively and the averages were 23.62 and $22.77 \%$ and drying efficiencies during different days of drying for the dryer and natural drying were

(42.93, 17.01 and 2.62\%), (37.09, 15.36 and 4.49\%) on first, second and third drying day, for okra respectively and the averages were 20.85 and $18.98 \%$. The drying efficiency reduced during successive days of drying. The reason for the reduction in efficiency on the second day is because the amount of water in the products were lower than in the first day . Also, surface moisture on the first drying day contributes to higher efficiency. On the third drying day, the efficiency further reduced due to the same reason.

\section{Thermal efficiency of the solar collector and the dryer:}

The thermal performance of the solar collector can be described in terms 
of several parameters which are usually employed to assess that performance

performance.

\section{1- Solar energy available (Q):}

Table (6) shows the solar energy available, it ranged from 285 to $416 \mathrm{~W}$.

\section{2- Absorbed solar energy (Qa):}

Table (6) shows the absorbed solar energy, it ranged from 242.25 to $353.60 \mathrm{~W}$.

\section{3 - Absorption efficiency ( $\eta \mathbf{a})$ :}

Table (6) shows the absorption efficiency, it ranged from 84.99 to $85.00 \%$.

\section{4 - Useful heat gain to storage $(Q c)$ :}

Table (6) shows the useful heat gain to storage, it ranged from 33.50 to $125.46 \mathrm{~W}$

\section{5- Heat transfer efficiency $(\eta \mathbf{h})$ :}

Table (6) shows the heat transfer efficiency, it ranged from 10.00 to $38.84 \%$.

\section{6- Solar collector heat losses $(\mathrm{QL})$ :}

Table (6) shows the Solar collector heat losses, it ranged from 187.91 to $301.40 \mathrm{w}$.

\section{7- Overall thermal efficiency $\left(\boldsymbol{\eta}_{\mathrm{s}}\right)$ :}

Table (6) shows the overall thermal efficiency, it ranged from 8.50 to $33.01 \%$.

\section{Conclusion}

Three crops were subjected to drying in the passive crop dryer. The crop samples were also open-sun dried as control and the weight losses and temperature were taken. The solar drying system was designed and manufactured in El-Zagazig, Sharkia governorate. Mint leaves, okra and grapes were dried in the dryer and same samples in the open- air (control). From the analysis of the results:

1. The maximum stagnation temperature attained in the dryer is 66 $\mathrm{C}^{\mathrm{o}}$, the corresponding values of solar radiation and ambient temperature were $832 \mathrm{~W} / \mathrm{m}^{2}$ and $36^{\circ} \mathrm{c}$, respectively.

2. The overall heat loss coefficient of the dryer varied between 21.56 and $28.34 \mathrm{~W} / \mathrm{m}^{2} \mathrm{c}$.

3. All the drying process occurred in the falling rate period, starting from the initial moisture content (83 wb or $488 \mathrm{db} \%$ for mint), (88.5 wb or $770 \mathrm{db} \%$ for okra) and (78 wb or $354 \mathrm{db}$ for\% grapes) to the final moisture content after drying were (1.18 and $19 \mathrm{db} \%$ for mint), (43 and $108 \mathrm{db} \%$ for okra) and (3.8 and 65.8 $\mathrm{db} \%$ for grapes), for (solar dryer and natural drying) respectively. 
4. The assessment of the drying rate of the crops in the solar dryer and in open-sun gives an average of 7.68 and $7.40 \mathrm{~g} / \mathrm{h}$ for mint leaves, $7.17 \mathrm{~g} / \mathrm{h}$ and $5.92 \mathrm{~g} / \mathrm{h}$ for grapes and $7.08 \mathrm{~g} / \mathrm{h}$ and $5.91 \mathrm{~g} / \mathrm{h}$ for okra.

5. Drying efficiencies during different days of drying for the dryer and natural drying were (34.27, 20.32 and 11.65\%), (40.31, 8.88 and $5.46 \%$ ) on first, second and third drying day, for grapes respectively and the averages were 22.05 and 18.21\%,drying efficiencies during different days of drying for the dryer and natural drying were $(60.92,7.11$ and $2.84 \%),(55.51,9.82$ and $2.98 \%$ ) on first, second and third drying day, for mint respectively and the averages were 23.62 and $22.77 \%$ and drying efficiencies during different days of drying for the dryer and natural drying were $(42.93,17.01$ and $2.62 \%),(37.09,15.36$ and $4.49 \%)$ on first, second and third drying day, for okra respectively and the averages were 20.85 and $18.98 \%$.

Table 6: Solar collector thermal performance and efficiency.

\begin{tabular}{|c|c|c|c|c|c|c|c|c|}
\hline Time & $\begin{array}{c}\text { Solar } \\
\text { Rad. } \\
\mathrm{W} / \mathrm{m}^{2}\end{array}$ & $\begin{array}{c}\text { Av. } \\
\text { energy, } \\
(\mathrm{Q}), \mathrm{W}\end{array}$ & $\begin{array}{c}\text { Abs. } \\
\text { solar } \\
\text { energy, } \\
\left(\mathrm{Q}_{\mathrm{a}}\right), \\
\mathrm{W}\end{array}$ & $\begin{array}{c}\text { Abs. } \\
\text { effi., } \\
\left(\eta_{\mathrm{a}}\right), \%\end{array}$ & $\begin{array}{c}\text { Useful } \\
\text { heat } \\
\text { gain, } \\
\left(\mathrm{Q}_{\mathrm{c}}\right), \\
\mathrm{W}\end{array}$ & $\begin{array}{c}\text { Heat } \\
\text { transfer } \\
\text { effi., } \\
\left(\eta_{\mathrm{h}}\right), \%\end{array}$ & $\begin{array}{c}\text { Solar } \\
\text { collector } \\
\text { heat } \\
\text { losses, } \\
\left(\mathrm{Q}_{\mathrm{L}}\right),\end{array}$ & $\begin{array}{c}\text { Overall } \\
\text { thermal } \\
\text { effi., } \\
\left(\eta_{\mathrm{s}}\right), \\
\%\end{array}$ \\
\hline $10: 00$ & 788 & 394.00 & 334.90 & 85.00 & 33.50 & 10.00 & 301.40 & 8.50 \\
\hline $11: 00$ & 817 & 408.50 & 347.22 & 84.99 & 102.60 & 29.50 & 244.61 & 25.11 \\
\hline $12: 00$ & 829 & 414.50 & 352.32 & 84.99 & 121.45 & 34.47 & 230.86 & 29.30 \\
\hline $13: 00$ & 832 & 416.00 & 353.60 & 85.00 & 125.64 & 35.53 & 227.96 & 30.20 \\
\hline $14: 00$ & 723 & 361.50 & 307.27 & 84.99 & 119.35 & 38.84 & 187.91 & 33.01 \\
\hline $15: 00$ & 723 & 361.50 & 307.27 & 84.99 & 100.51 & 32.71 & 206.75 & 27.80 \\
\hline $16: 00$ & 570 & 285.00 & 242.25 & 85.00 & 50.25 & 20.74 & 192.00 & 17.63 \\
\hline
\end{tabular}


PROCESS ENGINEERING

\section{REFERENCES}

Abdel-Galil, H.S. and El-Nakib A.A.(2008).Effect of Natural Convection Solar Drying on Quality of Peppermint. Misr J. Agric. Eng. 25(2): 513-534.

Akpinar, E. K. (2010). Drying of mint leaves in a solar dryer and under open sun: Modeling, performance analyses. Journal of Energy Conversion and Management, 51 pp. 2407-2418.

Al-Juamily, K.A.J; Khalifa, A.J.N. and Yassen, T.A. (2007). Testing of the performance of a fruit and vegetable solar drying system in Iraq. College of Engineering, Al-Nahrin University, Baghdad, Iraq. Desalination 209 (2007) 163-170.

Butter, J.L, and Goodrum, J.W. (1998). "Crop Drying Using Solar Energy". CRC Handbook of Engineering in agriculture. Vol.111.CRC Press,Inc.

Doymaz, I.(2011). Drying of Green Bean and Okra Under Solar Energy. Chemical Industry \& Chemical Engineering Quarterly 172 199-205.

Ezekoyi, B.A. and Enebe, O.M. (2006). "Development and performance Evaluation of Modified Integrated Passive Solar Grain Dryer". Pacific Journal of Science and Technology 7(2):185-190.

Gallali, Y.M.; Abujnah, Y.S.; Bannani, F.K.(2000). Preservation of fruits and vegetables using solar dryer: a comparative study of natural and solar drying, III; chemical analysis and sensory evaluation data of the dried samples (grapes, figs, tomatoes and onions). Renewable Energy; 19:203-12.

Lahsasni, M. Kouhila, M. Mahrouz and J. T. Jaouhari (2004). Drying kinetics of prickly pear fruit (Opuntia ficus indica). Journal of Food Engineering Volume 61, Issue 2, February 2004, Pages 173-179.

Mohamed M. A. ; Gamea, G. R. ; and Keshek, M. H.(2010). Drying Characteristics of Okra by Different Solar Dryers. Misr J. Ag. Eng., 27(1): $294-312$. 
Pangavhane, D. R.; Sawhney, R. L. and Sarasvadia, P. N. (2002). Design and development and performance of testing of a new natural convection solar dryer, Energy, 27, 579-590.

Radwan, M.S. (2002). Utilization of solar energy for drying grapes under Egyptian climatic condition. Misr. J. Ag., (1: 100- 112).

Shewen, E. C., Hollands, K. G. T. and Remick, C. D. (1980)."Development of A Fixed Position, Fixed Configuration Air Heating Solar Collector, Solar Energy Project," Report No. Coll-9, National Research Council, Canada, Ottawa.

Togrul, I.T.; D. Pehlivan (2004). Modelling of thin layer drying kinetics of some fruits under open-air sun drying process. Faculty of Engineering, Department of Chemical Engineering, Frat University, Kimya Muh. Bolumu, 23279, Elazg, Turkey. Journalof-Food-Engineering. 2004; 65(3): 413-425.

\section{الملخص العربي}

دراسة اداء مجفف شمسى لبعض المحاصيل ( النعناع والعنب والبامية)

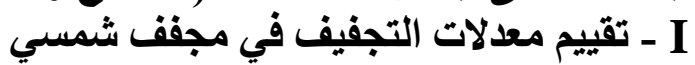

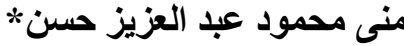

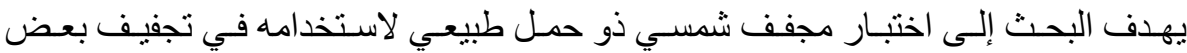

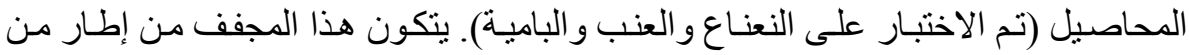

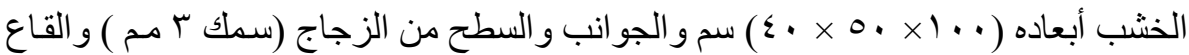

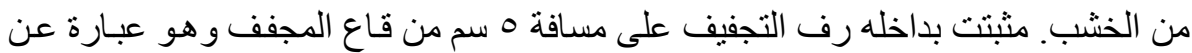

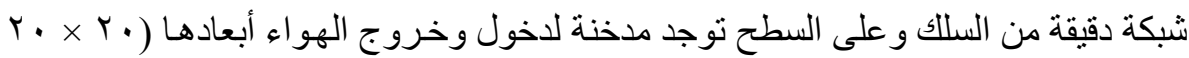

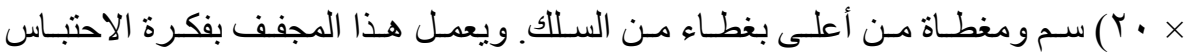

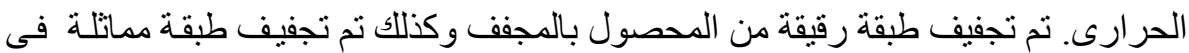

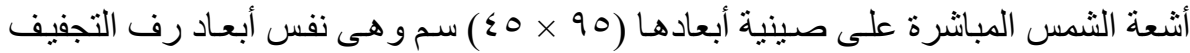

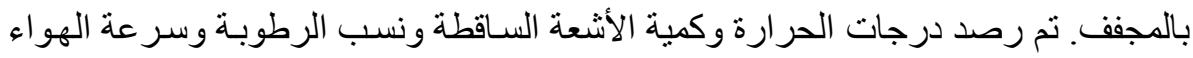
داخل المجف وخفارجة.

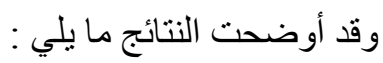

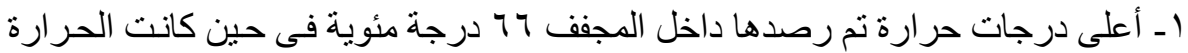

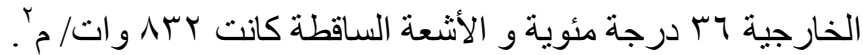

"أستاذ مساعد - قسم الهندسة الزراعية - كلية الزراعة - جامعة الزقازيق - مصر. 


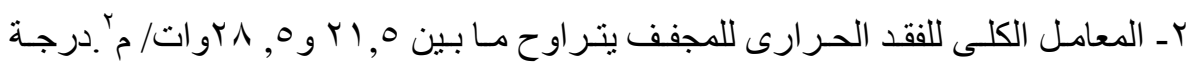
مئوية تقريبا.

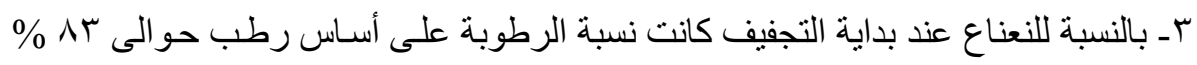

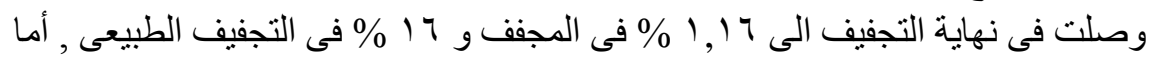

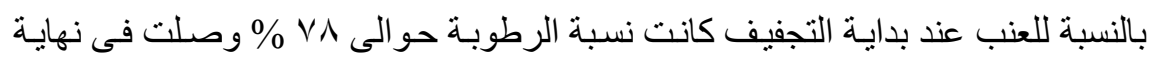

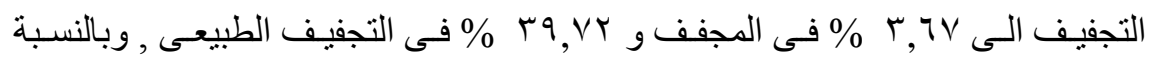

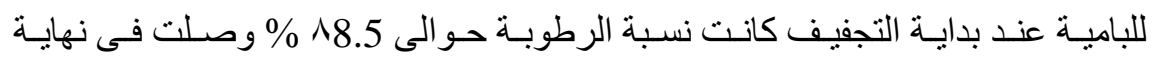

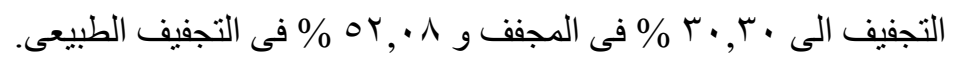

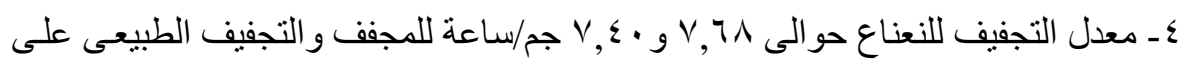

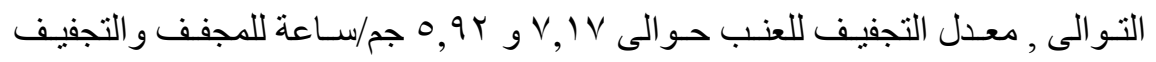

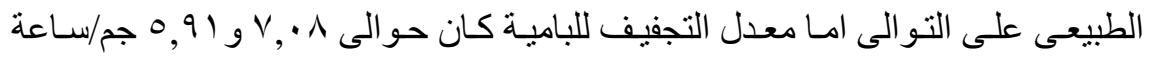

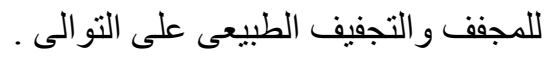

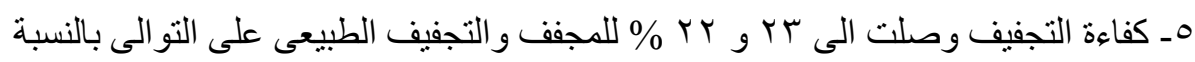

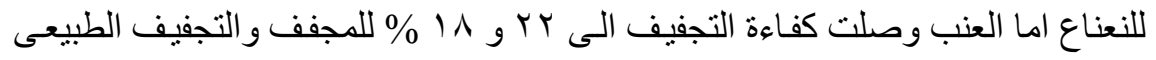

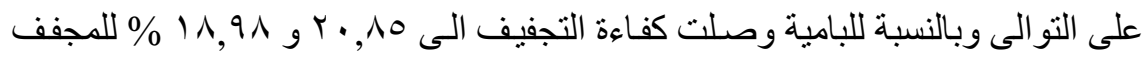

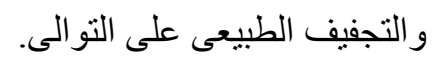

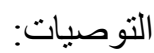

1 ـ يمكن تصنيع المجفف بو اسطة المز ارعين الصغخار أو ربـات البيوت باستخدام خامـات بسيطة ومتوفرة. r- يمكن استخدام المجف مع تجفيف منتجات زر اعية أخرى.

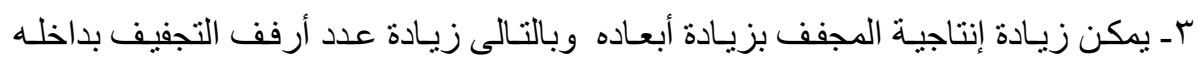
وكذللك يمكن تزويده بوحدة تخزين الطاقة للاستفادة منها فى التجفيف ليلا. 